\title{
Sucrose synthase expression pattern in the rhythmically growing shoot of common oak (Quercus robur L.)
}

\author{
Rozenn Le HIR*, Sandrine Pelleschi-Travier, Jean-Daniel ViÉMONT, Nathalie LeDUC \\ UMR SAGAH A-462, Laboratoire « Morphogenèse des Ligneux », UFR Sciences, 2 boulevard Lavoisier, 49045 Angers Cedex 01, France
}

(Received 19 May 2004; accepted 24 March 2005)

\begin{abstract}
In the search for a trophic control of rhythmic growth of young oak seedlings, sucrose synthase accumulation, localization and activity were studied in the apex, underlying internodes and leaves, during the second flush of shoot growth. The use of an anti-SuSy antibody raised against the Vicia faba protein allowed the detection of SuSy, which showed a $90 \mathrm{kDa}$ subunit. This antibody, used to immunolocalize the SuSy protein in oak revealed a positive signal in the reserve parenchyma tissues of the apex and in the leaf vascular tissues and underlying internodes. The study of SuSy activity along with the growth pattern of the different organs, suggested that SuSy may be involved in the control of rhythmic growth through the mobilization of sucrose in storage tissues and through loading/unloading processes. Such activities would help to bring enough nutrients to support the high morphogenic and growth processes during the rhythmic growth of the shoot.
\end{abstract}

common oak / rhythmic growth / bud / sugar metabolism / sink strength

Résumé - Localisation et activité de la saccharose synthase au cours de la croissance rythmique de l'axe aérien du chêne pédonculé (Quercus robur L.). Afin d'évaluer l'existence d'un contrôle trophique dans la croissance rythmique, l'accumulation, la localisation et l'activité de la saccharose synthase ont été étudiées au sein de l'apex, de l'entre-nœud sous-jacent et des feuilles au cours de la deuxième vague de croissance chez le chêne pédonculé. L'utilisation d'un anticorps anti-SuSy de Vicia faba a permis de détecter la protéine SuSy chez le chêne, qui présente une sous-unité de $90 \mathrm{kDa}$. Cet anticorps a révélé un signal positif dans les parenchymes de réserves de l'apex et dans les tissus vasculaires des feuilles et des entre-noeuds sous-jacents. L'étude de l'activité SuSy au cours de la croissance des différents territoires suggère que cette enzyme pourrait être impliquée dans le contrôle de la croissance rythmique au travers de la mobilisation des réserves glucidiques et des processus de chargement/déchargement phloémien. Ces activités apporteraient l'énergie nécessaire aux processus de morphogenèse et de croissance observés durant la croissance rythmique de la tige.

chêne pédonculé / croissance rythmique / bourgeon / métabolisme glucidique / force de puits

\section{INTRODUCTION}

Common oak (Quercus robur L.) shows an endogenous growth rhythm of the shoot axis under natural conditions [15]. This growth rhythm, which can easily be reproduced under controlled conditions, is characterized by the production of a flush every 25 days, after an active growth period of 14 days characterized by elongation of the stem axis and production of different types of leaves [5]. Several hypotheses have been suggested to explain the determinism of rhythmic growth: trophic, hormonal or hydric control $[5,8,9]$. Among these hypotheses, control through trophic competition has most often been investigated. Barnola et al. [4] studied cDMO accumulation (a lipophilic acid whose accumulation indicates an increase in membrane permeability) and showed that the shoot apex, the stem and the leaves displayed successively the largest sink strength during the flush. These authors therefore suggested, that the successive access to more nutrients for each organ of the shoot explained its temporarily increased growth activity and induced the rhythm. To increase our understanding of trophic control of rhythmic growth, we are currently studying carbohydrate metabolism in this system. Here, we report on sucrose synthase (UDP-d-glucose:d-fructose2- $\alpha$-glucosyltransferase, SuSy, EC 2.4.1.13), which catalyses the reversible conversion of sucrose and UDP into UDP-glucose and fructose. SuSy is ubiquitous in higher plants and assigns a variety of important roles. It is the predominant sucrose cleavage enzyme in cereal endosperm and in storage organs such as tubers, fruits, seed or immature leaves [24, 28]. Sucrose synthase in these carbohydrate sink organs provides substrates for respiration [29],

\footnotetext{
* Corresponding author: nathalie.leduc@univ-angers.fr
} 
starch [7] and cell wall synthesis [3]. A positive correlation between sucrose synthase activity, sink strength and sucrose import has been demonstrated in many sink organs, suggesting a role for this enzyme in carbohydrate partitioning between sink and source organs [24, 28, 30]. In addition, SuSy appears to play a key role in supplying energy for loading and unloading in phloem by providing substrate for respiration [16].

In this paper, sucrose synthase is studied through the complementary aspects of protein accumulation, tissue localisation as well as activity within the apex, the underlying internodes, the young leaves and the mature leaves during the second flush of growth. Changes in sucrose synthase distribution and activity are discussed in the light of its possible role in the control of rhythmic growth.

\section{MATERIALS AND METHODS}

\subsection{Plant material}

Common oak (Quercus robur L.) seedlings were grown from acorns. After a two weeks' germination in pots filled with moist vermiculite at $16^{\circ} \mathrm{C}$, young seedlings were transferred to hydroponic culture on INRA-Morizet nutrient solution [18] in a greenhouse at $25^{\circ} \mathrm{C}$ $\left( \pm 2{ }^{\circ} \mathrm{C}\right)$ with a $16 \mathrm{~h}$ photoperiod. The irradiance from 3 fluorescent tubes averaged $190 \mu \mathrm{mol} \mathrm{m} \mathrm{m}^{-2} \mathrm{~s}^{-1}$. Under these culture conditions, common oak produced a new flush of growth every 25 days.

\subsection{Sampling procedure}

Three key stages of oak development, described by Alatou et al. [2], were chosen for all the studies: the 2nd day with bud swelling, the 7 th day, with linear stem elongation, small and epinastic leaves and the 14th day, with maximal leaf expansion and cessation of stem elongation. For each stage, three organs were collected from the second flush: (i) apex (shoot apical meristem plus leaf primordia), (ii) green expanding leaves and (iii) underlying internodes (portion of stem between the first developing green leaf and the apex). Mature leaves of the first flush were added. For enzyme extractions, each sample was made up from at least fifteen plants and the results are means \pm the standard deviation of two different cultures $x$ three replicates. All samples were harvested within the same 1-h period in the morning in order to reduce variations due to daily fluctuations of plant metabolism. Tissues were immediately frozen in liquid nitrogen and stored at $-80^{\circ} \mathrm{C}$ until assay.

For measurements of sucrose and glucose + fructose concentrations, statistical analysis was performed using the Instat software and the Student's $t$ test $(p \leq 0.05)$.

\subsection{Protein gel blot analysis}

Liquid nitrogen-frozen plant tissues were ground, and the proteins from $20 \mathrm{mg}$ of powder were extracted on ice with 10 volumes $(\mathrm{w} / \mathrm{v})$ of extraction buffer $(50 \mathrm{mM}$ Tris- $\mathrm{HCl}, \mathrm{pH} 8.5,1 \%$ [w/v] polyvinylpolypyrrolidone (PVPP), $20 \mathrm{mM} \beta$-mercaptoethanol, $1 \%$ [w/v] SDS, 5 mM EDTA, 5 mM EGTA, $1 \mathrm{mM}$ DTT, and $1 \mathrm{mM}$ phenylmethylsulfonyl fluoride). After centrifugation for $30 \mathrm{~min}$ at $16000 \mathrm{~g}$ at $4{ }^{\circ} \mathrm{C}$, the supernatant was collected and resuspended in loading buffer $(500 \mathrm{mM}$ Tris, pH 6.8, 10\% SDS, $10 \%$ glycerol, $1 \%$ DTT and $0.01 \%[\mathrm{v} / \mathrm{v}]$ bromophenol blue) to a final concentration of $1 \mu \mathrm{g} / \mu \mathrm{L}$. Protein samples (20 $\mu \mathrm{g}$ per lane) were separated by $10 \%$ SDS-PAGE and blotted onto PVDF membranes. The immunological detection of SuSy was performed using a polyclonal antibody raised against the denatured SuSy protein of Vicia faba (a gift from Dr Ross H.A. [22]) diluted at 1/1000 prior to incubation with anti-rabbit IgG (Sigma). The protein-antibody complex was detected using chemiluminescence ECL, western-blotting system (Bio-rad).

\subsection{Enzyme extraction and assays}

For each sample, an extract was obtained after grinding frozen tissues with a glass rod in an Eppendorf tube containing fine sand (diameter $<10 \mu \mathrm{m})$. Extraction buffer ( $50 \mathrm{mM}$ Hepes-NaOH $(\mathrm{pH} 7.5), 1 \%$ [w/v] polyvinylpolypyrrolidone, $5 \mathrm{mM} \mathrm{MgCl}_{2}, 1 \mathrm{mM} \mathrm{Na}_{2}$ EDTA, $2.6 \mathrm{mM}$ dithiotreitol, $0.02 \%$ Triton $\mathrm{X} 100,0.6 \%$ bovine serum albumine) was added twice to a final volume of $200 \mu \mathrm{L}$ for apices and underlying tissue samples or of $500 \mu \mathrm{L}$ for leaf samples. The extract was centrifuged for $3 \mathrm{~min}$ in a microcentrifuge at $12000 \mathrm{~g}$ and $4{ }^{\circ} \mathrm{C}$. After centrifugation, the supernatant was desalted on G25 Sephadex columns equilibrated with $50 \mathrm{mMHepes}-\mathrm{NaOH}$ (pH 7.5), $15 \mathrm{mM} \mathrm{MgCl}_{2}, 1 \mathrm{mM}$ $\mathrm{Na}_{2}$ EDTA, $2.6 \mathrm{mM}$ dithiotreitol and $0.1 \%$ bovine serum albumin. SuSy activity was assayed on $50 \mu \mathrm{L}$ of desalted extract in a reaction mixture composed of $50 \mathrm{mM}$ Hepes- $\mathrm{NaOH}(\mathrm{pH} 7), 10 \mathrm{mM} \mathrm{MgCl}_{2}$, $1 \mathrm{mM}$ EDTA, $2.6 \mathrm{mM}$ DTT, $100 \mathrm{mM}$ sucrose, $1 \mathrm{mM}$ ATP, $0.4 \mathrm{mM}$ NAD, 4.2 U hexokinase, $3.5 \mathrm{U}$ phosphoglucoisomerase; $2 \mathrm{U}$ glucose$6-\mathrm{P}$-deshydrogenase. The reaction was initiated by adding $10 \mathrm{mM}$ UDP to the mixture and incubated at $30^{\circ} \mathrm{C}$ and the kinetic formation of NADH was measured at $340 \mathrm{~nm}$.

\subsection{Sucrose and reducing sugars (glucose + fructose) contents}

The supernatant previously obtained was boiled for 3 min and centrifuged at $12000 \mathrm{~g}$ for $5 \mathrm{~min}$. Sucrose and glucose + fructose contents were then determined by enzymatic assays, as described previously [19].

\subsection{Immunohistochemistry of $\mathrm{SuSy}$}

Samples were fixed for $4 \mathrm{~h}$ in FAA $(3.7 \%$ [v/v] formalin, $5 \%$ [v/v] acetic acid, and $50 \%[\mathrm{v} / \mathrm{v}]$ ethanol, in water) at $4{ }^{\circ} \mathrm{C}$. The fixed tissues were then dehydrated in an alcohol series (50 to $100 \%$ ), embedded in paraffin and sectioned at $10 \mu \mathrm{m}$ thickness. Sections were incubated overnight at room temperature in a blocking solution $(1 \% \mathrm{BSA}[\mathrm{w} / \mathrm{v}]$, $0.3 \%$ Triton X-100 [v/v] in TBS). In order to reduce the aspecific linkage, slides were incubated for $20 \mathrm{~min}$ with an unconjugated anti-rabbit antiserum raised in goat diluted 1/50 in TBS (Sigma) before incubation for $2 \mathrm{~h}$ at room temperature with the primary antibody (anti-rabbit polyclonal antibody given by Ross et al. [22]) or with the pre-immune serum diluted 1/500 in blocking solution. The slides were then washed six times in TBS and incubated for $20 \mathrm{~min}$ in unconjugated anti-rabbit antiserum in goat diluted 1/50 in TBS before incubation for $1 \mathrm{~h}$ at room temperature with the secondary antibody (Goat anti-rabbit IgG alkaline phosphatase conjugate, Promega, France) diluted 1/7500 in TBS. After five washes in TBS, sections were incubated with NBT/BCIP. Once color had developed on the sections (2-3 h exposure), sections were rinsed in stop buffer (100 mM Tris, $\mathrm{pH} \mathrm{8,1}$ mM EDTA), dehydrated, mounted in Entellan (Merck) and photographed.

\section{RESULTS}

\subsection{Protein accumulation (Figs. 1A-1D)}

The use of the polyclonal antibodies raised against Vicia faba SuSy, on total protein extracts from apices (Fig. 1A), underlying tissues (Fig. 1B), young leaves (Fig. 1C) and 

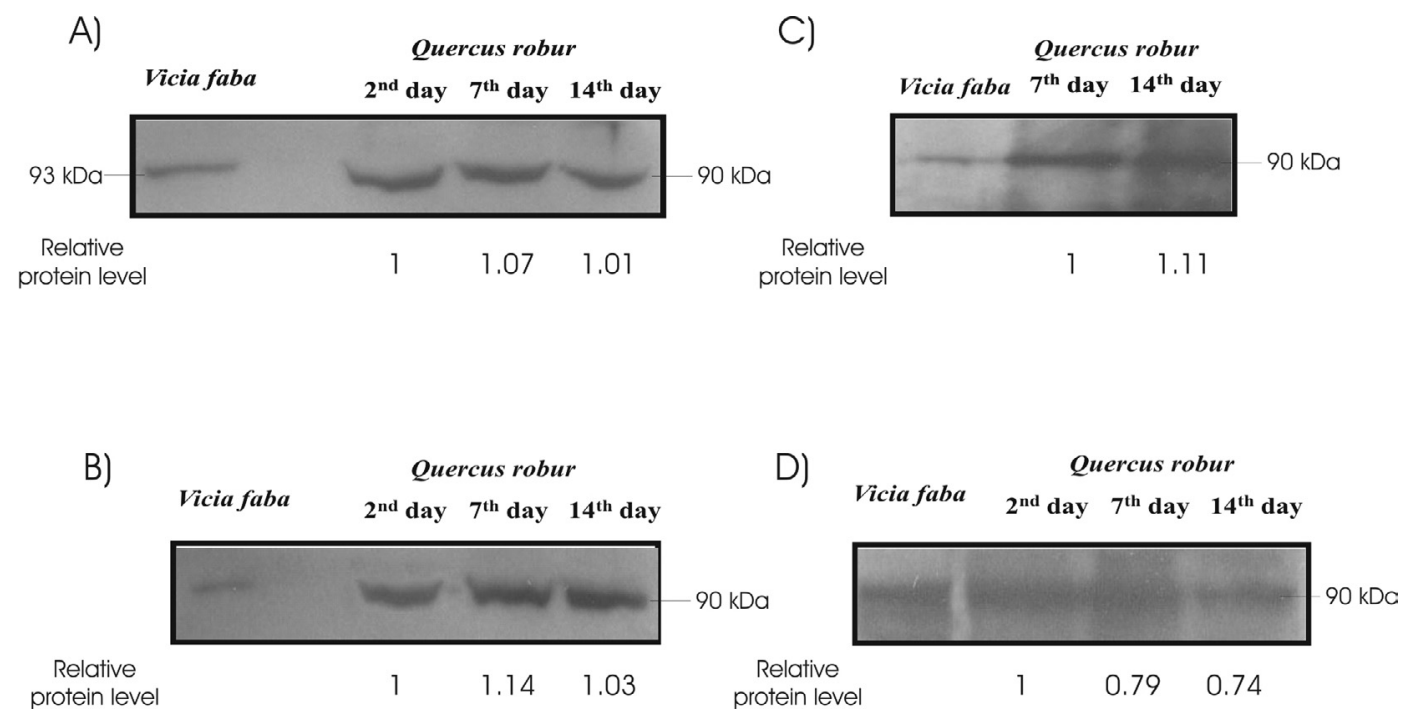

Figure 1. Western-blot analysis showing the accumulation of SuSy in total protein extracts from Vicia faba and from apices (A), underlying tissues $(\mathbf{B})$, young leaves $(\mathbf{C})$ and mature leaves $(\mathbf{D})$ of Quercus robur L. plants on the 2nd, 7th and 14th days of the second flush of growth. Blots were produced using $20 \mu \mathrm{g}$ of protein in each lane of the gel. The SuSy antiserum from Vicia faba was used as a probe in a 1:1000 dilution. Band intensities were quantified using the Scion Image software and the relative amount of SuSy protein during the 2nd day sample were set as 1.

Table I. Sucrose synthase activity in different organs of the oak plants during the second flush of growth. Sampling of young leaves on the 2nd day was impossible due to their small size. Activity was expressed in nmol NADH h $\mathrm{h}^{-1} \mathrm{~g}^{-1} \mathrm{FW}$. Values are the means $\pm \mathrm{SE}$ of six samples from two different cultures. UD: undetected.

\begin{tabular}{|c|c|c|c|}
\hline \multirow[b]{2}{*}{ Plant part } & \multicolumn{3}{|c|}{ Enzyme activity (nmol NADH $\mathrm{h}^{-1} \mathrm{~g}^{-1} \mathrm{FW}$ ) } \\
\hline & 2nd day & 7th day & 14th day \\
\hline Apex of the second flush & $410 \pm 140$ & UD & UD \\
\hline Underlying nodes of the second flush & UD & UD & UD \\
\hline Young leaves of the second flush & & $260 \pm 80$ & $260 \pm 80$ \\
\hline Mature leaves of the first flush & UD & UD & $600 \pm 200$ \\
\hline
\end{tabular}

mature leaves (Fig. 1D) of oak, showed that this antibody recognized a single band with a molecular mass of $90 \mathrm{kDa}$. This size of the oak protein subunit was slightly smaller than that of Vicia faba, estimated to be $93 \mathrm{kDa}$ (Fig. 1). Western blots revealed that the SuSy subunit was present in all organs of common oak, and at all stages tested. Densitometry analysis of protein bands revealed very weak difference in subunit accumulation between dates in apices, underlying nodes and young leaves of the second flush. Only a decrease in mature leaves of the first flush between days 2 and 7 were observed (Fig. 1D).

\subsection{Protein SuSy localisation (Fig. 2)}

In order to investigate the distribution of the SuSy protein during the second flush of growth, an immunohistological analysis was performed in apices, underlying internodes and leaves. Identical localizations were evidenced whatever the stage. In the apices, SuSy protein accumulated in the medular and cortical parenchyma whereas it was absent of the differentiating vascular tissue or of the shoot apical meristem (Figs. 2A and 2B). Unlike in the apices, analysis of underlying internodes sections showed that SuSy protein accumulated in the vascular tissues (Figs. 2C and 2D) and more precisely in the phloem companion cells and in the xylem parenchyma (Figs. 2E and 2F). In mature leaves of the first flush (data not shown), as well as in young leaves of the second flush, a vascular localization of SuSy protein was also observed (Figs. $2 \mathrm{G}$ and $2 \mathrm{H}$ ).

\subsection{Sucrose synthase activity (Tab. I)}

SuSy activity was not detected in all organs (Tab. I). Indeed, in apices, SuSy was active only on the 2nd day although its presence was detected by protein gel blot and immunolocalisation after this stage. Similarly in the underlying internodes, presence of SuSy protein but not its activity could be detected. In contrast, SuSy activity was detected in young leaves of the second flush, and its value was stable during the 7th and the 14th days. In the mature leaves of the first flush, enzymatic activity of SuSy was only detected on the 14th day of the second flush. 

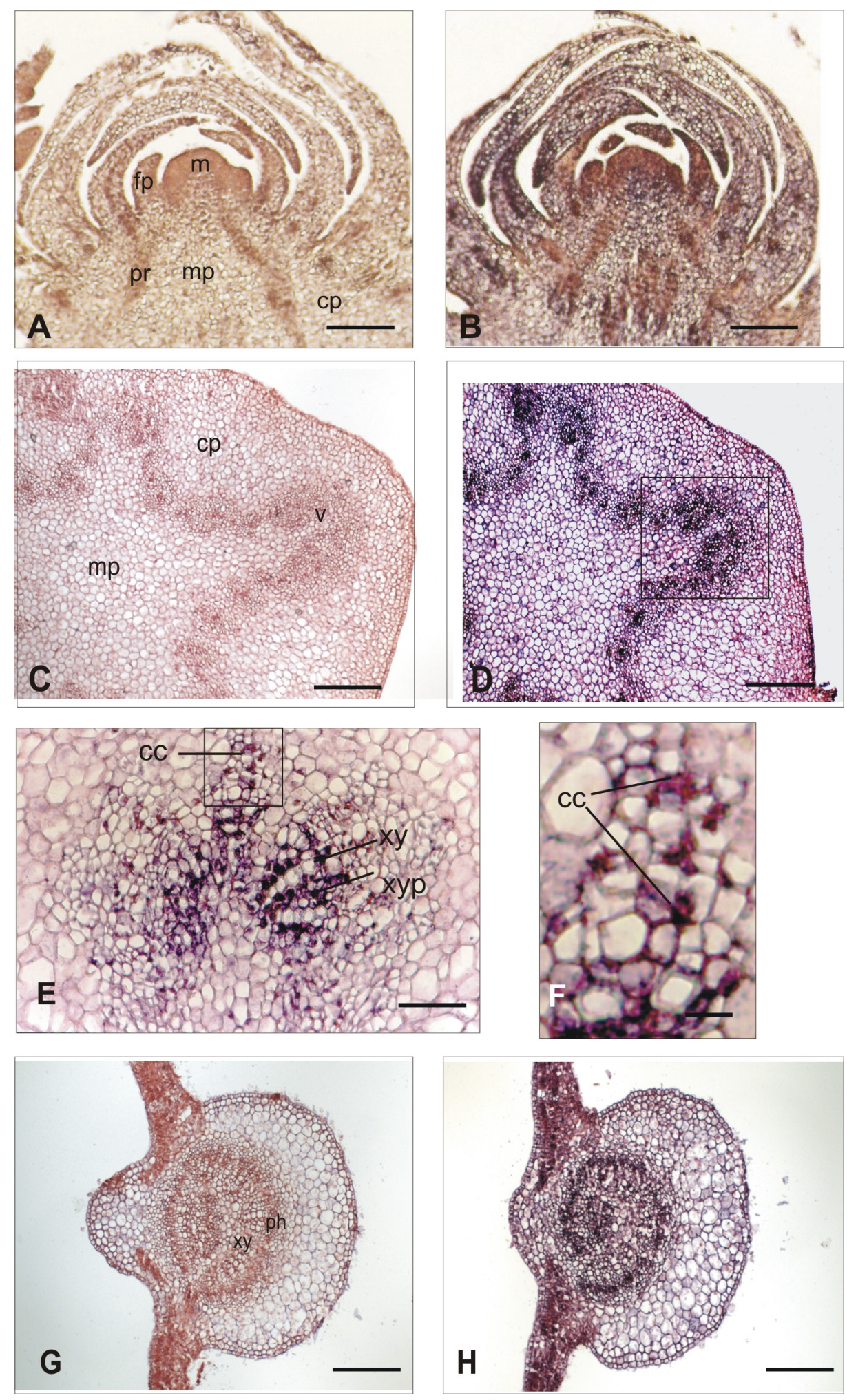

Figure 2. Localisation of SuSy protein in cross sections of apex (A-B), underlying internodes $(\mathbf{C}-\mathbf{F})$ and young leaves $(\mathbf{G}-\mathbf{H})$ on the 14 th day of the second flush in common oak (Quercus robur L.). A, C and G: cross sections incubated with pre-immune serum. B, D, E (detail from D), $\mathbf{F}$ (detail from $\mathbf{E}$ ), and $\mathbf{H}$ cross sections incubated with the anti-SuSy antibody of Vicia faba. Cc: companion cell, cp: cortical parenchyma, fp: foliar primordium, m: meristem, mp: medular parenchyma, ph: phloem, pr: procambium, v: vasculature, xy: xylem, xyp: xylem parenchyma. Bars $=100 \mu \mathrm{m}(\mathbf{A}, \mathbf{B}), 300 \mu \mathrm{m}(\mathbf{C}, \mathbf{D}), 150 \mu \mathrm{m}(\mathbf{E}), 30 \mu \mathrm{m}(\mathbf{F}), 350 \mu \mathrm{m}(\mathbf{G}, \mathbf{H})$. 
Table II. Sucrose concentrations in different organs of oak seedlings during the second growth flush. Sampling of young leaves was impossible during day 2 due to their small size. Means \pm SE of six samples from two different cultures. Different letters indicate statistically significant difference $(p \leq 0.05)$ : for one organ during the stages considered (first letter), for one stage among organs (second letter).

\begin{tabular}{lrrr}
\hline & & Sucrose content $\left(\mathrm{mg} \mathrm{g}^{-1} \mathrm{FW}\right)$ \\
\cline { 2 - 3 } Plant part & 2nd day & 7 th day & 14 th day \\
\hline Apex of the second flush & $13.59 \pm 4.93^{\mathrm{a}, \mathrm{a}}$ & $8.88 \pm 2.40^{\mathrm{a}, \mathrm{a}}$ & $10.44 \pm 2.85^{\mathrm{a}, \mathrm{a}}$ \\
Underlying nodes of the second flush & $4.27 \pm 0.57^{\mathrm{a}, \mathrm{b}}$ & $4.62 \pm 1.37^{\mathrm{a}, \mathrm{b}}$ & $4.14 \pm 0.83^{\mathrm{a}, \mathrm{b}}$ \\
Young leaves of the second flush & & $20.4 \pm 14.4^{\mathrm{a}, \mathrm{a}}$ & $19.53 \pm 11.8^{\mathrm{a}, \mathrm{c}}$ \\
Mature leaves of the first flush & $37.78 \pm 6.2^{\mathrm{a}, \mathrm{c}}$ & $36 \pm 2.2^{\mathrm{a}, \mathrm{c}}$ & $31.96 \pm 6.7^{\mathrm{a}, \mathrm{c}}$ \\
\hline
\end{tabular}

Table III. Glucose + fructose concentrations in different organs of oak seedlings during the second growth flush. Sampling of young leaves was impossible during day 2 due to their small size. Means \pm SE of six samples from two different cultures. Different letters indicate statistically significant difference ( $p \leq 0.05$ ): for one organ during the stages considered (first letter), for one stage among organs (second letter).

\begin{tabular}{|c|c|c|c|}
\hline \multirow[b]{2}{*}{ Plant part } & \multicolumn{3}{|c|}{ Glucose + fructose content $\left(\mathrm{mg} \mathrm{g}^{-1} \mathrm{FW}\right)$} \\
\hline & 2nd day & 7th day & 14 th day \\
\hline Apex of the second flush & $7.6 \pm 1.07 \mathrm{a}, \mathrm{a}$ & $8.68 \pm 2.51^{\mathrm{a}, \mathrm{a}}$ & $12.74 \pm 3.5^{\mathrm{a}, \mathrm{a}}$ \\
\hline Underlying nodes of the second flush & $2.41 \pm 0.85^{\mathrm{a}, \mathrm{b}}$ & $2.63 \pm 0.28^{\mathrm{a}, \mathrm{b}}$ & $4.41 \pm 1.52^{\mathrm{a}, \mathrm{b}}$ \\
\hline Young leaves of the second flush & & $14.58 \pm 5.44^{\mathrm{a}, \mathrm{c}}$ & $14.24 \pm 8.36^{\mathrm{a}, \mathrm{a}}$ \\
\hline Mature leaves of the first flush & $5.18 \pm 1.06^{\mathrm{a}, \mathrm{c}}$ & $6.98 \pm 1.43^{\mathrm{a}, \mathrm{a}}$ & $5.05 \pm 2.6^{\mathrm{a}, \mathrm{b}}$ \\
\hline
\end{tabular}

\subsection{Soluble sugars content (Tabs. II and III)}

The sucrose concentration of the apex, underlying nodes, young leaves of the second flush and mature leaves of the first flush measured during the 2nd, 7th and 14th day of the second flush, is shown in Table II. While no significant variations in sucrose concentration were measured in each organ during these developmental stages, Table II shows that for all stages, the sucrose concentration of mature leaves of the first flush is $3 \times$ higher than in other organs. The lowest sucrose concentration is measured in underlying nodes of the second flush, with a mean of $4.5 \mathrm{mg} \mathrm{g}^{-1} \mathrm{FW}$.

Variations in reducing sugar (glucose + fructose) concentrations are shown in Table III. As for sucrose concentration, no significant variations were found between the $2 \mathrm{nd}$, 7th and 14th day of the second flush of growth in each organ. The highest reducing sugar concentrations were measured in the young leaves of the second flush, with a mean of $14 \mathrm{mg} \mathrm{g}^{-1} \mathrm{FW}$. The lowest concentration was observed in the underlying nodes of the second flush, with a mean of $2 \mathrm{mg} \mathrm{g}^{-1} \mathrm{FW}$.

Tables II and III also show that at each stage, the apex of the second flush contains more sugar (sucrose and reducing sugar) than the underlying nodes of the same flush. Comparison between the apex and young leaves of the second flush show that young leaves displayed slightly larger sucrose and reducing sugar concentrations than those of the apex. In mature leaves of the first flush, reducing sugar concentration is signif- icantly lower than in young leaves of the second flush (Tab. III) while for sucrose concentration, an inverse pattern is measured (Tab. II).

\section{DISCUSSION}

\subsection{Detection of SuSy in a heterologous system}

Plant sucrose synthases are generally reported to be homo or heterotetrameric proteins with native molecular masses ranging from 280 to $540 \mathrm{kDa}$ and subunit molecular masses in the range of $83-100 \mathrm{kDa}$. A single $90 \mathrm{kDa}$ band was detected in oak protein samples using the anti-SuSy antibody from Vicia faba. Since in the same western blot, the antibody also recognized the $93 \mathrm{kDa}$ subunit of Vicia faba, described in the literature [12], it is very likely that the $90 \mathrm{kDa}$ band corresponds to an oak SuSy subunit. Recently, the release of the complete genome sequence of Arabidopsis has shown that the SuSy subunit is encoded by six distinct genes [6]. Each of these genes is differentially expressed depending on the organ type and the environmental conditions, suggesting a transcriptional regulation of SuSy [6]. At the protein level, SuSy is also controlled by numerous posttranslational modifications (for review [11]). In cell cultures of sycamore, for example, western blot analyses of SuSy did not show noticeable differences in protein levels while changes in the SuSy activity were measured. Phosphorylation of SuSy seems to inactivate it in this species [21]. A similar 
mechanism could be suggested in oak and therefore explain the fact that SuSy was detected in all organs and at each date, but not its activity.

\subsection{Differential activity and localization of $\mathrm{SuSy}$ during the second flush}

The data reported here indicate that sucrose synthase activity varies during the second flush of growth and that a different cellular localization of SuSy protein is observed among organs.

\subsubsection{Apex}

In oak apices, SuSy activity was only detected during the 2nd day of the flush. At this date, SuSy activity was higher than in other shoot organs. Since SuSy is considered a good indicator of the sink strength of an organ [24], the shoot apex on the 2nd day of the flush appears therefore to be the strongest sink of the shoot. This fact is supported by the non-vascular localization of SuSy protein observed here. Indeed, in maize, this localization is linked with sink tissue activity [10]. Furthermore, measurements of sugar concentrations (sucrose and glucose + fructose) show that in comparison with the underlying nodes, the apex has a higher concentration of these components. Our results are in agreement with those of Barnola et al. who showed, by using the incorporation of $\mathrm{cDMO}$ as a indicator of organ sink strength in oak, that on the 2nd day, the apex is a stronger sink than the other organs [4].

We also localized the SuSy protein in storage tissues of the bud, i.e., medular and cortical parenchyma, but not in the shoot apical meristem (SAM). Correlation between the localization of this protein and its high activity at a stage when the organogenic activity of the SAM is highest, suggests that SuSy activity could contribute to sucrose mobilization in storage tissues in order to supply hexoses and energy to support morphogenetic and growth activity in the SAM. Similar conclusions on the contribution of SuSy to the maintenance of growth processes, through the hydrolysis of sucrose from storage tissues, were shown previously [28].

Our results also show that SuSy did not accumulate in the shoot apical meristem sensu stricto. In other species, the localization of SuSy has seldom been observed in the meristem region. At the transcript level, two opposite localization patterns are described. In maize and potato, no accumulation of SuSy transcripts is observed in the apical meristem [10, 26] while in tomato Pien et al. [20] showed localization of SuSy transcripts in the SAM and more precisely in a localized region of the meristem flank which includes the earliest stages of primordium bulge formation.

\subsubsection{Leaves and underlying internodes}

In contrast to the apices, in young and mature leaves as well as in the underlying internodes, SuSy accumulated preferentially in the vascular tissues of the phloem and in particular in phloem companion cells of the underlying internodes. Such localization is in agreement with the results of Kleines et al. [13], who showed a high level of SuSy transcripts in phloem cells in the stem of Craterostigma. Similarly, in mature leaves of eggplant and in young fruit of lemon [25] a high level of SuSy activity was also measured in vascular bundles. SuSy was also localized specifically in the companion cells in maize leaves [17] and in castor bean [27]. This localization in common oak leads also to suggest an involvement of SuSy in controlling sugar fluxes in the vascular system. Indeed, it has been suggested that the hydrolysis of sucrose by SuSy in phloem cells could either constitute a source of energy for loading/unloading of the sucrose [27] or for the provision of UDP-glucose for callose synthesis in the sieve plates [14]. In common oak, the leaves of the first flush are source organs for young leaves of the second flush [1]. Our results show that SuSy activity in mature leaves is high on the 14th day and localized in phloem cells. This suggests that the hydrolytic activity of SuSy in mature leaves could provide energy for sucrose loading in the phloem, thus contributing to the export of sucrose towards the young expanding leaves of the second flush. This hypothesis is reinforced by results obtained in young leaves. Indeed, in this organ, SuSy activity was detectable from the 7th day to the 14th day of the flush and localized in the vascular tissues. At this stage, young leaves seemed to be strong sink and SuSy could participate in the unloading of the sucrose provided by the mature leaves in order to support the rapid growth of young leaves.

\section{CONCLUSION}

By a multiple approach (enzymatic activity, western blot and immunolocalization), this study provides a detailed analysis of sucrose synthase expression in a woody species, common oak. Results obtained in this rhythmically growing species showed that Susy activity was highest in apices on the 2nd day, followed by young leaves on the 7 th day and finally mature leaves on the 14th day. The apices and young leaves organs also contained high soluble sugar concentrations. These facts support the hypothesis of a trophic competition between apices and young leaves. Differential tissue localization of SuSy was also shown in these organs. In the light of these results, this localization was linked with two major roles for SuSy: mobilization of sucrose in storage tissues (apex) and involvement in loading/ unloading processes (leaves and underlying nodes). In order to determine if trophic competition is the primary signal that triggers rhythmic growth, further studies should be made on carbohydrate metabolism in the early stages of a flush (for example, each day between the 2 nd and 7 th days). Moreover, the role of other enzymes involved in the hydrolysis of sucrose in plants should be studied. Indeed, enzymes such as invertases also have an important role in the regulation of source-sink relationships [23] and should also be considered. These questions are currently being addressed using this system and will be reported elsewhere.

Acknowledgements: We would like to thank Dr. Ross H.A. (Scottish Crop Research Institute, Dundee, UK) for the gift of the antibody antiSuSy of Vicia faba. The authors are grateful to the Vilmorin Company for providing acorns, and to M. Poirier, and Mrs. Chalain S. for their help in oak cultivation. 


\section{REFERENCES}

[1] Alaoui-Sossé B., Ricaud S., Barnola P., Dizengremel P., Rhythmic growth and carbon allocation in Quercus robur. Sucrose metabolizing enzymes in leaves, Physiol. Plant. 96 (1996) 667-673.

[2] Alatou D., Barnola P., Lavarenne S., Gendraud M., Caractérisation de la croissance rythmique du chêne pédonculé, Plant Physiol. Biochem. 27 (1989) 275-280.

[3] Amor Y., Haigler C.H., Johnson S., Wainscott M., Delmer D.P., A membrane-associated form of sucrose synthase and its potential role in synthesis of cellulose and callose in plants, Proc. Natl. Acad. Sci. USA 92 (1995) 9353-9357.

[4] Barnola P., Alatou D., Lecointe A., Lavarenne S., Étude biologique et biochimique du déterminisme de la croissance rythmique du chêne pédonculé (Quercus robur). Effets de l'ablation des feuilles, Ann. Sci. For. 21 (1990) 619-631.

[5] Barnola P., Crochet A., Payan E., Gendraud M., Lavarenne S., Modifications du métabolisme énergétique et de la perméabilité dans le bourgeon apical et l'axe sous-jacent au cours de l'arrêt de croissance momentané de jeunes plants de chênes, Physiol. Veg. 24 (1986) 307-314.

[6] Baud S., Vaultier M.-N., Rochat C., Structure and expression profile of the sucrose synthase multigene family in Arabidopsis, J. Exp. Bot. 55 (2004) 397-409.

[7] Chourey P., Nelson O., The enzymatic deficiency conditioned by the shrunken-1 mutations in maize, Biochem. Genet. 14 (1976) 1041-1055.

[8] Davenport T.L., Pearce D.W., Rood S.B., Correlation of endogenous gibberellic acid with initiation of mango shoot growth, J. Plant Growth Regul. 20 (2000) 308-315.

[9] Hallé F., Martin R., Étude de la croissance rythmique de l'hévéa (Hevea brasiliensis Müll. arg., Euphorbiacées Crotonoïdées), Adansonia Sér. 2, 8 (1968) 475-503.

[10] Hänggi H., Fleming A.J., Sucrose synthase expression pattern in young maize leaves: implications for phloem transport, Planta 214 (2001) 326-329.

[11] Hardin S.C., Winter H., Huber S.C., Phosphorylation of the amino terminus of maize sucrose synthase in relation to membrane association and enzyme activity, Plant Physiol. 134 (2004) 1427-1438.

[12] Heim U., Weber H., Baumlein H., Wobus U., A sucrose-synthase gene of Vicia faba L.: expression patterns in developing seeds in relation to starch synthesis and metabolic regulation, Planta 3 (1993) 394-401.

[13] Kleines M., Elster R.C., Rodrigo M.J., Blervacq A.S., Salamini F., Bartels D., Isolation and expression analysis of two stress-responsive sucrose-synthase genes from the resurrection plant Craterostigma plantagineum (Hochst.), Planta 209 (1999) 13-24.

[14] Konishi T., Ohmiya Y., Hayashi T., Evidence that sucrose loaded into the phloem of a poplar leaf is used directly by sucrose synthase associated with various $\beta$-glucan synthases in the stem, Plant Physiol. 134 (2004) 1146-1152.
[15] Lavarenne-Allary S., Recherche sur la croissance des bourgeons du chêne et de quelques autres espèces ligneuses, Ann. Sci. For. 22 (1964) 1-203.

[16] Martin T., Frommer W.B., Salanoubat M., Willmitzer L., Expression of an Arabidopsis sucrose synthase gene indicates a role in metabolization of sucrose both during phloem loading and in sink organs, Plant J. 4 (1993) 367-377.

[17] Nolte K.D., Koch K.E., Companion-cell specific localization of sucrose synthase in zones of phloem loading and unloading, Plant Physiol. 101 (1993) 889-905.

[18] Payan E., Contribution à l'étude de la croissance rythmique chez de jeunes chênes pédonculés (Quercus pedunculata Ehrh.), Thèse de doctorat, Université Blaise Pascal, Clermont-Ferrand, 1983, p. 102.

[19] Pelleschi S., Rocher J.P., Prioul J.L., Effect of water restriction on carbohydrate metabolism and photosynthesis in mature maize leaves, Plant Cell Environ. 20 (1997) 493-503.

[20] Pien S., Wyrzykowska J., Fleming A.J., Novel marker genes for early leaf development indicate spatial regulation of carbohydrate metabolism within the apical meristem, Plant J. 25 (2001) 663-674.

[21] Pozueta-Romero J., Pozueta-Romero D., Gonzalez P., Etxeberria E., Activity of membrane-associated sucrose synthase is regulated by its phosphorylation status in cultured cells of sycamore (Acer pseudoplatanus), Physiol. Plant. 122 (2004) 275-280.

[22] Ross H.A., Davies H.V., Purification and characterization of sucrose synthase from the cotyledons of Vicia faba L., Plant Physiol. 100 (1992) 1008-1013.

[23] Sturm A., Invertases. Primary structures, functions, and roles in plant development and sucrose partitioning, Plant Physiol. 121 (1999) 1-7.

[24] Sung S.S., Xu D.P., Black C.C., Identification of actively filling sucrose sinks, Plant Physiol. 89 (1989) 1117-1121.

[25] Tomlinson P.T., Duke E.R., Nolte K.D., Koch K.E., Sucrose synthase in isolated vascular bundles, Plant Physiol. 121 (1991) 1-7.

[26] Vermerris W., Vreugdenhil D., Visser R.G.F., mRNA localization in in vitro grown microtubers of potato as a tool to study starch metabolism, Plant Physiol. Biochem. 39 (2001) 161-166.

[27] Wachter R., Langhans M., Aloni R., Gotz S., Weilmunster A., Koops A., Temguia L., Mistrik I., Pavlokvin J., Rascher U., Vascularization, high-volume solution flow, and localized roles for enzymes of sucrose metabolism during tumorigenesis by Agrobacterium tumefaciens, Plant Physiol. 133 (2003) 1024-1037.

[28] Wang F., Sanz A., Brenner M.L., Smith A., Sucrose synthase, starch accumulation, and tomato fruit sink strength, Plant Physiol. 101 (1993) 321-327.

[29] Xu D.P., Sung S.J., Loboda T., Kormanik P.P., Black C.C., Characterization of sucrolysis via the uridine diphosphate and pyrophosphate-dependent sucrose synthase pathway, Plant Physiol. 90 (1989) 635-642.

[30] Zrenner R., Salanoubat M., Willmitzer L., Sonnewald U., Evidence of the crucial role of sucrose synthase for sink strength using transgenic potato plants (Solanum tuberosum), Plant J. 7 (1995) 97-107. 